\title{
Editorial: Indonesian Industrialization and the Changing of Southeast Asia Geopolitics
}

We are proudly present our recently published Journal of ASEAN Studies. The Vol.2 No. 1 Issue is the third issue we have consistently published from December 2012. In this issue, the key topics examined by the writers focuses on the domestic politics of industrialization and the changing of East Asia Geopolitics. The current condition of East Asia geopolitics cannot be separated from the dynamics of political and economic issues faced in the domestic level by each country in East Asia particularly in ASEAN. In this issue, we focus on three main countries in East Asia and how they affect the dynamic of Southeast Asia geopolitics.

In this third edition, JAS covers four scholarly articles. First article entitled "An Industry without Industrialization: The Political Economy of The Failure of Indonesia's Auto Industry" written by Wang-pin Tai. In this article, he examines the puzzle why Indonesia could not create its own automotive industry. Having the largest auto market in Southeast Asia, Indonesia is supposed to have more favorable conditions than Thailand and Malaysia on the development of auto industry. Unlike Malaysia's auto industry that has its own national brand, Indonesia does not have a national auto brand, nor like Thailand as the largest auto exporting country in Southeast Asia, a Japanese scholar even contends that Indonesia's auto industry is "technologyless industrialization". In order to answer the question, he argues that the failure of Indonesia's auto industry has to do with the structural factors in Indonesia's political economy.

The last three articles analyze the implication of the changing domestic policy toward the geopolitics in East Asia and in particularly Southeast Asia. In the second article entitled "The US Rebalance Policy and the Management of Power Politics in Asia Pacific", Anak Agung Banyu Perwita and Denisa Rizkiya examine how the US Rebalance Policy introduced by the U.S. President Barack Obama early in his first administration in 2010, marked specific changing to the U.S. foreign policy like never before. Their article tries to analyze how the U.S. rebalance towards Asia policy, a term used for the U.S.' foreign policy influenced the regional stability in Asia-Pacific region. They argue that the U.S. continuously views South and South East Asia, including the Indian Ocean, as a crucial driver for America's economic growth and prosperity throughout the 21st century. Numerous numbers of cooperation and partnership have been done to enhance the ties between the U.S. and the regions. The U.S. presence and involvement in most essential regional meetings and summits can also be seen as an effort to seek opportunities, politically, economically, as well as security.

The third article focuses on the changing leadership in China and how it impacts the perception of Southeast Asia. In the article entitled "Challenges against Xi Jinping: an ASEAN Perspective", written by Abdullah Dahana and Kelly Rosalin examine various challenges, including nationalism as the most serious issue faced by $\mathrm{Xi}$ Jinping as a leader elected through compromise. They argue that although factionalism still exists, it has been converted to collaboration among all factions within the Chinese Communist Party (CCP). The election of Xi 
Jinping to the presidency of the People's Republic of China (PRC) and to the position as General Secretary of the Chinese Communist Party (CCP) is therefore, as the result of cooperation among factions.

The fourth article discusses the changing domestic politics in Japan and how it affect Japan's relations with their neighbor especially ASEAN countries. The article entitled "Japan's Renaissance and Its Effect to ASEAN" written by Syafril Hidayat describe how Japan has developed a new security policy against China in East China Sea, which has increased tension in that region. Furthermore, the article analyzes how Japan's new leadership under Shinzo Abe, who has conservative political view, has unbeatable policy against China's hegemony. By using bargaining model of war, this article argues that Japan's security policy will determine overall situation in South China Sea or particularly in East China Sea: whether it will remain of high threat or balance of threat rather than balance of power, or it will face possible conflict in the future.

We believe that these four articles might contribute toward the discussion on current Southeast Asia's International Relations and Comparative Politics. We also like to announce several changes in our editorial board. Our editorial board Prof. Zainuddin Djafar has passed way in May 2014. The whole editorial team and board show our deepest condolences and sympathy to his family. We hope that his works and his tremendous contribution to this journal will always be source of inspiration for all of us.

Furthermore, we are delighted to welcome our new editorial board; Assoc. Prof. Darwis Khudori from University of Le Havre, France; Assistant Prof. Gautam Kumar Jha from Jawaharlal Nehru University, India; Dr. K.K. Ramachandran from GRD Institute of Management, Coimbatore, India; and Dr. Baiq Wardhani from Airlangga University, Indonesia. Their participation in our editorial board has made our editorial board composition covers America, Europe, South Asia, and Indonesia. It shows our strong commitment to enhance quality of this journal.

Besides academics, our editorial board has been strengthening by the presence of Dr. Marty Natalegawa, Minister of Foreign Affairs, Republic of Indonesia and Dr. Dino Patti Djalal, Vice Minister of Foreign Affairs, Republic of Indonesia. Their practical expertise will for sure enhance the merit of our Journal.

Jakarta, 25 July 2014

\section{Tirta Nugraha Mursitama, PhD}

Editor-in-Chief 